\title{
INDUCTION OF SPAWNING \\ IN THE TROPICAL WALKING CATFISH (Clarias batrachus) BY CONTROLLING WATER LEVEL AND TEMPERATURE
}

\author{
M. ZAIRIN JR. ${ }^{1}{ }^{1}, K^{\prime}$. FURUKAWA ${ }^{2)}$ AND K. AiDA ${ }^{2)}$ \\ ${ }^{1)}$ Department of Aquaculture, Faculty of Fisheries and Marine Science, \\ Bogor Agricultural University, Bogor, Indonesia \\ ${ }^{2}$ Department of Aquatic Bioscience, Faculty of Agricultural and Life Sciences, The \\ University of Tokyo, Tokyo, Japan
}

\begin{abstract}
This experiment was carried out to confirm the role of water level and water temperature in inducing the spawning of tropical walking catfish. Mature males and females reared under $23-25{ }^{\circ} \mathrm{C}$, were paired and induced to spawn by controlling water level and water temperature.

Decreasing water level and returning it to its original level resulted in a low spawning rate (less than $6.7 \%)$ at $23{ }^{\circ} \mathrm{C}$. Decreasing water level with simultaneous increase in water temperature, followed by returning the respective levels to their originals gave high spawning rates (41.7 - 50\%); whereas the same treatment but without any water temperature decreased when the water level was returned to the initial level, gave a low spawning rate (16.7 \%). Increasing water level only, failed to induce spawning. A high spawning rate was obtained also when changes in water level were carried out under high temperature of $28^{\circ} \mathrm{C}$. No fish spawned in the absence of the environmental stimulation.

From the results, it is confirmed that water level and temperature play important roles in inducing spawning of tropical walking catfish. Changes in water temperature probably increase the sensitivity of fish to the change in water level. Prolonged exposure to high water temperature could also improve the sensitivity of fish.
\end{abstract}

Key words: Walking catfish / spawning / water level / water temperature

\section{INTRODUCTION}

In the previous reports (Zairin et al. 1992a,b), it has been suggested that under long term rearing and constant warm water temperature, female catfish maintained conditions of maturity for an extended period, and no spontaneous spawning has been seen to occur. On the other hand, from the practical point of view, one of the constraints in employing environmental factors in inducing the fish to spawn in the pond is a low spawning rate. Therefore, it is necessary to investigate the ability of this fish to respond to environmental stimulation for the induction of spawning.

• Corresponding author: e-mail address: zairinm@indo.net.id; Fax: 62-251-622541 18 
In nature, both environmental and physiological factors are considered as important cues in triggering final oocyte maturation, ovulation and spawning in teleosts. In tropical areas, natural water temperature is relatively high, and water level amplitude is large in association with the occurrence of the rainy and dry seasons. It has been reported that peaks of spawning activity of tropical species are often associated with rainfall and flood (Lam 1983; Lam and Munro 1987; Munro 1990). Several species have been reported to spawn in relation to the change in water level, for example weakly electric fish (Eigenmannia virescens) (Kirschbaum 1979) and the African catfish (Glorias gariepinus) (Bruton 1979). Moreover, mimicking environmental phenomena in nature, e.g. by regulating water level, has been commonly employed in aquaculture in Southeast Asian countries to induce tropical walking catfish to spawn (Areerat 1987; Tarnchalanukit 1987; Knud-Hansen et al. 1990). However, little is known on the combinatory effects of water level and water temperature in the action of inducing spawning. Therefore, experiments were conducted to study the effects of water temperature and water level in the induction of spawning in walking catfish

\section{MATERIALS AND METHODS}

\section{Experimental fish}

Two month-old walking catfish were transported from Bogor, Indonesia to Japan, and reared in an indoor concrete pond (width $\mathrm{x}$ length $\mathrm{x}$ depth $=1.5 \times 3 \times 0.5 \mathrm{~m}$ ) supplied with running freshwater of deep-well origin at the Fisheries Laboratory, The University of Tokyo, Maisaka, Shizuoka Prefecture. During this rearing period, fish were subjected to a photoperiodic cycle of 12L(Light):12D(Dark), and relatively constant water temperature $\left(23-25^{\circ} \mathrm{C}\right)$ throughout the year. Fish were fed twice per day with commercially available trout dry pellets no. 5 (40\% protein, Chubu Shiryo, Co.) at a daily ration of $2-3 \%$ of body weight. Under the above stocking conditions, fish began to mature at the age of 9 months and thereafter; conditions of maturity were maintained without undergoing natural spawning.

Two experiments (I and II) were carried out. A week before the start of the experiment I, 15 pairs of fish were selected from the stock pond. Males weighing $325-400 \mathrm{~g}$ and females weighing 375-500 g were used. These fish were paired and placed in each compartment. At the end of the experiment I, all fish were replaced by a new group for experiment II. For this experiment, males weighing 250-375 g and females weighing 300-425 g were selected and paired.

\section{Experimental condition}

Five indoor concrete ponds $1 \times 3 \times 1 \mathrm{~m}$ in size were used. Each pond was divided transversely into three compartments by framed plastic nets, so that every 
compartment was $1 \times 1 \times 1 \mathrm{~m}$ (Fig. Ib). Each compartment was equipped with one spawning box, which was placed in the compartment only during the observation period of spawning (day 14-24, 31-35, 45-55 in experiment I, day 11-25, 35-45 in experiment II).

The spawning boxes $30 \times 35$ x $42 \mathrm{~cm}$, were painted dark brown, with a hole of 12 $\mathrm{cm}$ in diameter (Fig. la). Half of the upper portion was made removable for checking for deposited eggs. An artificial plastic spawning nest made of soft plastic fibres was placed inside each box. The box was fixed in the corner of every compartment, in which 2-3 cm of its upper portion rose above that of water level.

Photoperiod was maintained at constant 12L:12D throughout the experiment, but water temperature and depth were varied according to the type of treatment. Limitation in sample numbers did not allow statistical analysis. Such experiments are very difficult to be carried out for a large number offish.

\section{Treatment}

Treatment A and A'. A sudden decrease in water level from $70 \mathrm{~cm}$ to $20 \mathrm{~cm}$ (in one hour) for 13 days (treatment A) or to $35 \mathrm{~cm}$ (in one hour) for 7-10 days (treatment A'), followed by an increase back to the original level of $70 \mathrm{~cm}$ (in one hour). Water temperature was maintained at $23 \pm 0.5^{\circ} \mathrm{C}$ during the experiments. On the day of water level increase, a spawning box was placed in each compartment. The boxes were checked everyday for deposited eggs for 10 days (treatment A) and for 4-10 days (treatment A'). For more details, refer to Fig. 2.

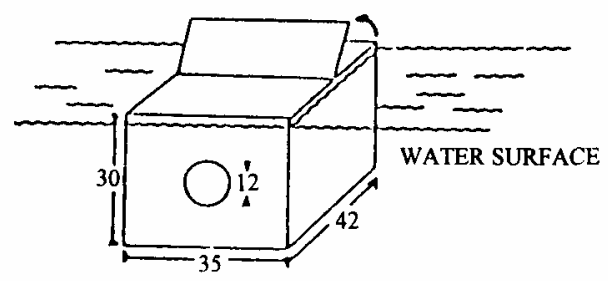

(a)

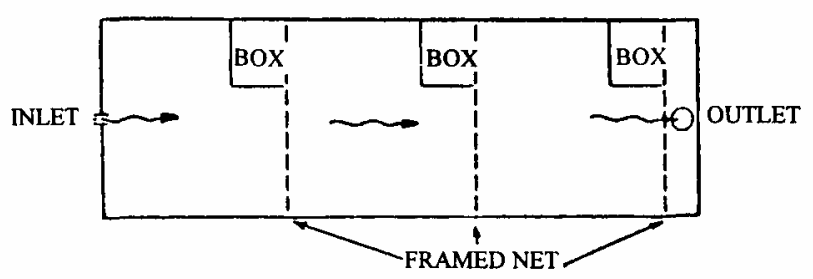

(b)

Figure 1. (a) spawning box and its placement relative to water surface. (b) pond compartments and box position in each compatmentent. 
BIOTROPIA NO. 16, 2001
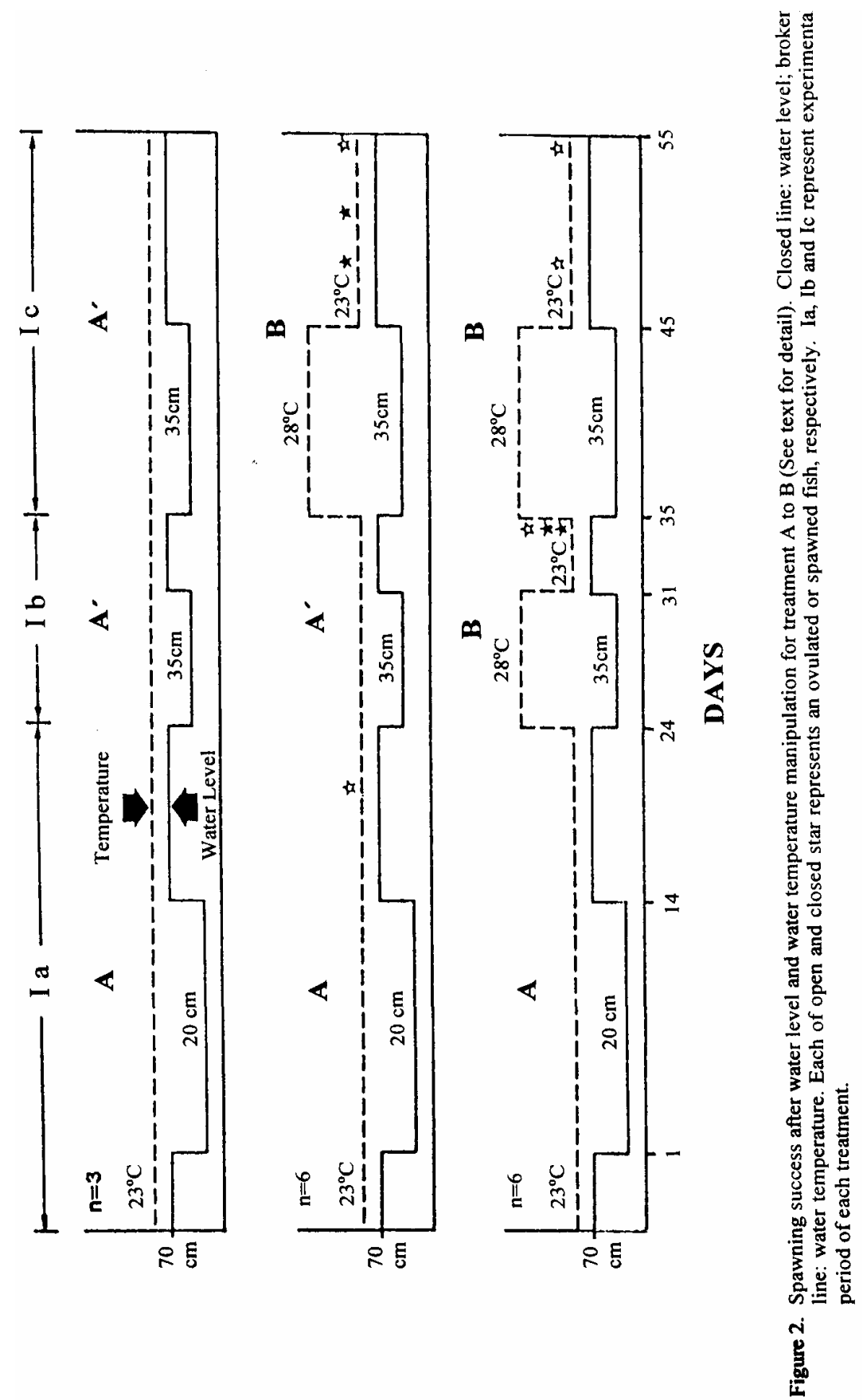
Treatment B. A sudden drop in water depth from $70 \mathrm{~cm}$ to $35 \mathrm{~cm}$ (in one hour), and an increase in temperature from $23{ }^{\circ} \mathrm{C}$ to $28^{\circ} \mathrm{C}$ (in six hours) were simultaneously carried out for 7-10 days, and after that, both water level and temperature were returned to their originals. On the day of water level increase, a spawning box was placed in each compartment. The boxes were checked everyday for deposited eggs for 4-10 days (Fig. 2).

Treatment C. Similar to treatment B, a sudden drop in water level from $70 \mathrm{~cm}$ to $35 \mathrm{~cm}$ (in one hour), and an increase in water temperature from $23^{\circ} \mathrm{C}$ to $28^{\circ} \mathrm{C}$ (in six hours) for 10 days were simultaneously carried out, but the temperature was maintained at $28^{\circ} \mathrm{C}$ while the water level was returned to its original (in one hour) after 10 days. On the day of water level increase, a spawning box was placed in each compartment. The boxes were checked everyday for deposited eggs for 14 days (Fig. 3).

Treatment $\mathrm{D}$ and $\mathrm{D}^{\prime}$. Only an increase in water temperature from $23^{\circ} \mathrm{C}$ to $28^{\circ} \mathrm{C}$ (in six hours) for 10 days (treatment D), and for 24 days (treatment D'), without accompanying water level manipulation. The duration of observation was 10 days. On days 11 and 35, a spawning box was placed in each compartment. The boxes were checked everyday for deposited egg for 14 days (treatment D) and for 10 days (treatment D'). For more details, refer to Fig. 3.

Treatment E. A sudden drop in water level from $70 \mathrm{~cm}$ to $35 \mathrm{~cm}$ (in one hour) at $23^{\circ} \mathrm{C}$ for 10 days and then return to the original water level at $28^{\circ} \mathrm{C}$. On the day of water level increase, a spawning box was placed in each compartment. The boxes were checked everyday for deposited eggs for 10 days (Fig. 3).

Treatment F. No manipulation. This treatment is regarded as controls for all experiments. Water temperature and water level were kept at $23^{\circ} \mathrm{C}$ and $70 \mathrm{~cm}$, respectively. At days 11 and 35, a spawning box was placed in each compartment. The boxes were checked everyday for deposited eggs for 10-14 days (Fig. 3).

\section{RESULTS AND DISCUSSIONS}

\section{Results Experiment I}

The results are presented in Fig. 2. During experiment la, the fish were subjected to treatment A. Out of 15 pairs employed, only one pair spawned (6.7\%).

During experiment Ib, fish were subjected to treatment A' and B. From 9 pairs of fish employed in treatment $A^{\prime}$, no fish spawned. In treatment $B$, however, the combination of water level and temperature manipulation gave a high spawning rate (50\%). Out of six pairs employed, three pairs spawned or ovulated.

During experiment Ic, fish were subjected also to treatment $A^{\prime}$ and $B$. The result was still in agreement with those of experiment Ib. No fish spawned in treatment A'. Treatment B again gave a high spawning rate (41.7\%). Out of 12 pairs of fish employed, five pairs spawned. 

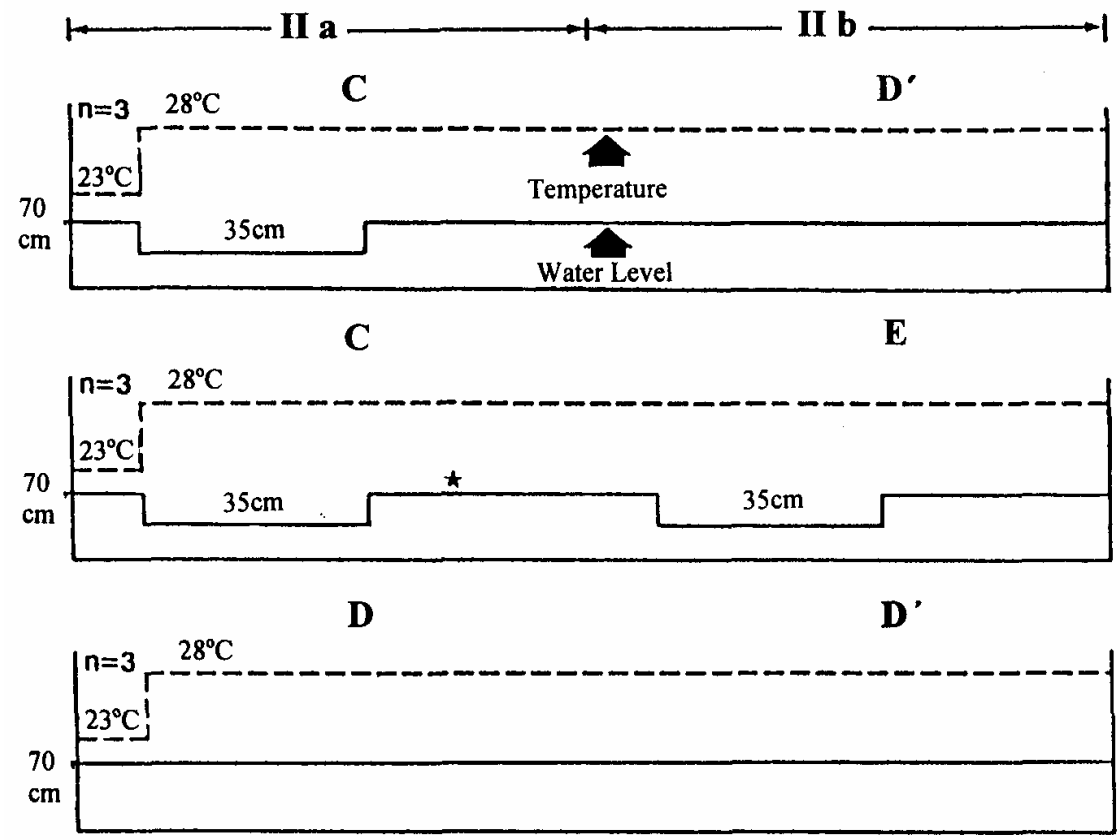

D $\quad \mathbf{E}$
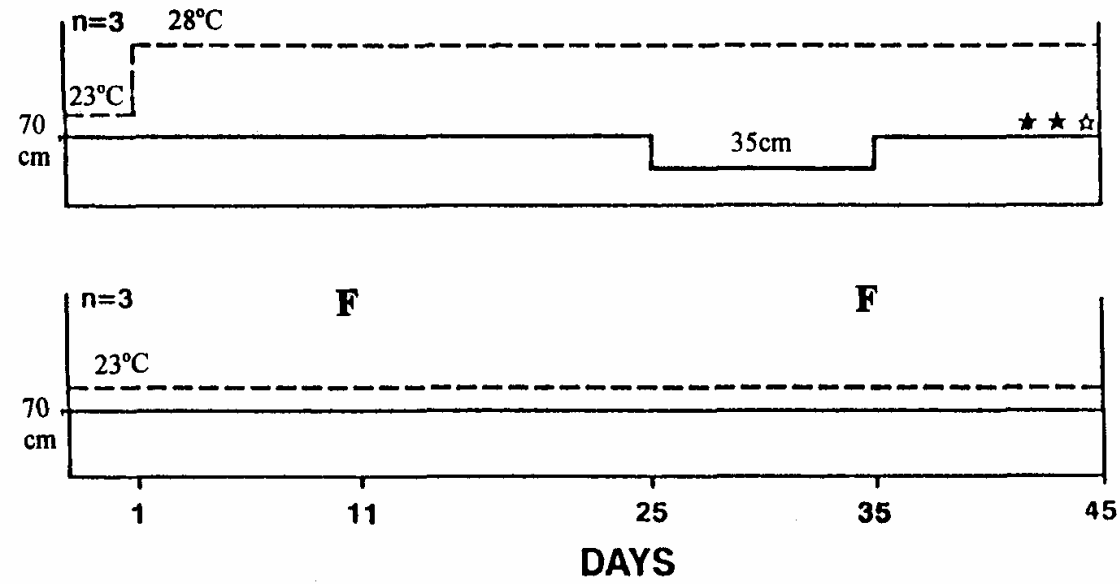

Figure 3. Spawning success after water level and water temperature manipulation for treatment C to F (See text for details). Closed line: water level; broken line: water temperature. Each of the open and closed star represents an ovulated or spawned fish, respectively. Ha and lib represent the experimental period of each treatment. 
Induction of spawning in the tropical walking catfish - M. Zairin JR. et al.

\section{Experiment II}

The results are presented in Fig. 3. During experiment Ha, the fish were subjected to treatment C, D and F. Treatment C, which was similar to treatment B, but without dropping water temperature upon increasing water level, gave a spawning rate of $16.7 \%$. Out of six pairs employed, one pair spawned. On the other hand, increasing only water temperature (treatment D) or no manipulation in water level and temperature (treatment F) could not induce spawning.

During experiment lib, the fish were subjected to treatment D', E and F. Manipulation of water level under $28^{\circ} \mathrm{C}$ (treatment E) gave a high spawning rate (50\%). Out of six pairs employed, three pairs spawned or ovulated. No fish spawned in treatment D' or F.

In our experimental conditions, at least three days (after the placement of spawning box) were needed to reach the ovulation or spawning. The results of all treatments are summarized in Table 1.

Table 1. Spawning success after water level and water temperature manipulation

\begin{tabular}{|c|c|c|c|c|}
\hline Treatment & $\begin{array}{c}\text { Treatment duration } \\
\text { (days) }\end{array}$ & $\begin{array}{l}\text { Number of } \\
\text { fish }\end{array}$ & $\begin{array}{l}\text { Number of spawned } \\
\text { fish }\end{array}$ & $\begin{array}{c}\text { Spawning rate } \\
(\%)\end{array}$ \\
\hline $\begin{array}{l}\text { A: a sudden decrease in water } \\
\text { level from } 70 \mathrm{~cm} \text { to } 20 \mathrm{~cm} \text {. }\end{array}$ & 13 & 15 & 1 & 6.7 \\
\hline 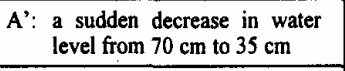 & $7-10$ & 12 & 0 & 0 \\
\hline $\begin{array}{l}\text { B: a sudden decrease in water } \\
\text { depth from } 70 \mathrm{~cm} \text { to } 35 \mathrm{~cm} \\
\text { and an increase in tempera- } \\
\text { ture from } 23^{\circ} \mathrm{C} \text { to } 28^{\circ} \mathrm{C} \text {. } \\
\text { After the treatment, water } \\
\text { level and temperature were } \\
\text { returned to their originals. }\end{array}$ & $7-10$ & 18 & 8 & $41.7-50.0$ \\
\hline $\begin{array}{l}\text { C: a sudden drop in water level } \\
\text { from } 70 \mathrm{~cm} \text { to } 35 \mathrm{~cm} \text { and an } \\
\text { increase in water temperature } \\
\text { from } 23^{\circ} \mathrm{C} \text { to } 28^{\circ} \mathrm{C} \text {. After } \\
\text { treatment temperature was } \\
\text { maintained at } 28^{\circ} \mathrm{C} \text { while } \\
\text { water level was returned to } \\
\text { its original. }\end{array}$ & 10 & 6 & 1 & 16.7 \\
\hline $\begin{array}{l}\text { D: an increase in water tempera- } \\
\text { ture from } 23^{\circ} \mathrm{C} \text { to } 28^{\circ} \mathrm{C} \text {, } \\
\text { without water level mani- } \\
\text { pulation. }\end{array}$ & 10 & 6 & 0 & 0 \\
\hline $\begin{array}{l}\text { D': Maintaining fish at } 28^{\circ} \mathrm{C} \text {, } \\
\text { without water level mani- } \\
\text { pulation }\end{array}$ & 24 & 6 & 0 & 0 \\
\hline $\begin{array}{l}\text { E: a sudden drop in water level } \\
\text { from } 70 \mathrm{~cm} \text { to } 35 \mathrm{~cm} \text { at } \\
23^{\circ} \mathrm{C} \text {, then returned to the } \\
\text { original water level at } 28^{\circ} \mathrm{C}\end{array}$ & 10 & 6 & 3 & 50.0 \\
\hline $\begin{array}{l}\text { F: water temperature and water } \\
\text { level kept at } 23^{\circ} \mathrm{C} \text { and } 70 \mathrm{~cm} \text {. }\end{array}$ & 10 & 6 & 0 & 0 \\
\hline
\end{tabular}




\section{Discussions}

Mimicking the environmental phenomenon to induce spawning in fish has been a common practice in aquaculture in Southeast Asian countries, including the use of the water level manipulation (Areerat 1987; Tarnchalanukit 1987; Knud-Hansen et al. 1990). Unfortunately, no scientific effort has been made to substantiate this interesting practice. Understanding this problem will add value to the development of the domestication of tropical wild edible river fish. Considering the typical physical conditions in the tropic and to simplify the problem, water temperature and water level have been chosen as variables. Both factors were chosen because changes in water levels of tropical river were usually accompanied by changes in water temperature. The possibility of photoperiod as an environmental cue has been omitted since our previous results showed that these fish were found mature throughout the year in Japan, regardless of photoperiod (Zairin et al. 1992a,b).

Environmental stimulation usually induces spawning by a long process through the hypothalamus-hypophysial-gonadal axis (Blazquez et al. 1998). And as expected, time elapses are needed between the stimulation and the initiation of spawning. Overall in this experiment, at least three days were needed for walking catfish to spawn. In the African catfish Clarias gariepinus, in which fish were kept in earthen ponds, a shorter time interval was sufficient (Bruton 1979). This difference may be due to the more complex physico-chemical conditions in the earthen pond. The possibility of more males needed to induce courtship behaviour has been disregarded since this fish is not a mass spawner.

Changes in water levels alone (treatment A) actually could induce spawning, although the spawning success was low (6.7\%). This means that the fish may be responsive to the fluctuation in water level after a long time exposure to a constant temperature and photoperiod condition. A low spawning success reflects a low sensitivity of fish to water level fluctuation. This low responsiveness may be due to relatively low water temperature $\left(23^{\circ} \mathrm{C}\right)$ employed in this experiment. This is supported by the fact that in the tropics such as Indonesia, the average water temperature in places where the fish are commonly cultured, is usually higher than $23^{\circ} \mathrm{C}$.

From the daily observation on the performance of fish in experiment la, we considered that lowering the water level to $20 \mathrm{~cm}$ gave insufficient space for fish to maneuver because the depth was less than the average length of fish employed. Thereafter, the minimum depth was increased to $35 \mathrm{~cm}$ (treatment A'). Although treatment $\mathrm{A}^{\prime}$ gave no spawned fish, we used $35 \mathrm{~cm}$ as the minimum depth.

The results from treatment $\mathrm{B}$, in which more fish spawned (41.7-50\%) when the change in water level was accompanied by the change in water temperature indicate the importance of water temperature amplitude. Furthermore, the results suggest that fluctuations in temperature could increase the sensitivity of fish to the water level manipulation. Further supporting evidence came from treatment $\mathrm{C}$ and 
D. Treatment C was similar to experiment B but without water temperature decrease upon the increase in water level; the spawning rate in treatment $C(16.7 \%)$ was lower than treatment B (41.7-50\%).

No spawning occurred under treatment $\mathrm{D}$ and $\mathrm{D}$ ' which indicated that increasing only the water level gave no stimulation on the fish to spawn. Treatment D and D' were similar, and differed only in the duration of exposure to high water temperature. Exposure to treatment $\mathrm{D}^{\prime}$ was longer than that of treatment $\mathrm{D}$.

Additionally, when changes in water level were carried out at a higher temperature of $28^{\circ} \mathrm{C}$ (treatment E), the spawning success was almost the same as those obtained when water fluctuation was accompanied by water temperature changes. These results suggest that changes in temperature could be replaced by prolonged exposure to higher temperature. Furthermore, this phenomenon indicates that temperature still plays an important role in the spawning of the tropical walking catfish.

From the practical point of view, the results from the best treatment of our experiments give a higher spawning success compared with those of fish farms. Calculation based on figures provided by Knud-Hansen (1990) indicates only less than $15 \%$ of spawning success; and in practice, $10 \%$ spawning success is regarded as an acceptable rate. Therefore, for practical purposes, the role of these factors should get more attention. Furthermore, we believe that combination of environmental factors with simple hormonal treatment could improve the spawning success further. Research in this area should receive more attention.

\section{ACKNOWLEDGMENT}

We express our thanks to all members of the Fisheries Laboratory of The University of Tokyo, Maisaka, Shizuoka Prefecture, for the facility for field experiments. We thank M. N. Wilder for reviewing the manuscript. This study was partially funded by a grant-in-aid for Scientific Research from the Ministry of Education, Science and Culture, Japan.

\section{REFERENCES}

Areerat, S. 1987. Clarias culture in Thailand. Aquaculture, 63, 355-362.

Blazquez, M.P., Bosnia, P.T., Eraser, E.J. Van Look, K.J.W., and V.L Trudeau, 1998. Fish as a model for the neuroendocrine regulation of reproduction and growth. Comp. Biochem. Physiol. PartC, 199, 345364.

Bruton, M.N. 1979. The breeding biology and early development of Clarias gariepinus (Pisces: Clariidae) in lake Sibaya, South Africa, with a review of breeding in species of the subgenus Clarias. Trans. Zool. Soc. London. 35, 1-45. 


\section{BIOTROPIA NO. 16, 2001}

Kirschbaum, F. 1979. Reproduction of the weakly electric fish Eigenmannia virescens (Rhamphichtydae, Teleostei) in captivity. Behav. Ecol. Sociobiol., 4, 331-355.

Knud-Hansen, C.F., Batterson, T.R., McNabb, C. D., Hadiroseyani, Y., Dana, D., and H.M Eidman,. 1990. Hatchery techniques for egg and fry production of Clarias batrachus (Linnaeus). Aquaculture, 89, 919.

Lam, T. J. 1983. Environmental influences in gonadal activity in fish. In: W.S. Hoar, D.J. Randall, and E.M. Donaldson (eds.), Fish Physiology, Vol. IX, Part B, p. 65-116, Academic Press, New York.

Lam, T.J., and A.D. Munro, 1987. Environmental control of reproduction in teleost: an overview. Proc. of the third Int. Symp. on Reprod. Physiol. of Fish. St. John's, Newfoundland, Canada, p. 279-288.

Munro, A.D. 1990. Tropical freshwater fish. In: A.D. Munro, A.P. Scott, and T.J. Lam. Reproductive seasonality in teleost: environmental influences, CEC Press, Boca Raton, Florida, p. 145-239

Tamchalanukit, W. 1987. Induced spawning of walking catfish, Clarias batrachus, by water level jegulation. Proc. of the Third Int. Symp. on Reprod. Physiol. of Fish. St. John's, Newfoundland, Canada, p. 138.

Zairin, M., Jr., Furukawa, K.., and K. Aida, 1992a. Induction of ovulation by HCG injection in the tropical

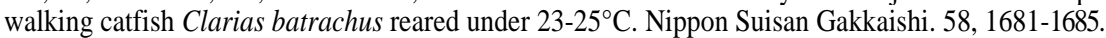

Zairin, M., Jr., Furukawa, K., and K. Aida, 1992b. Changes in ovarian maturity in the tropical walking catfish, Clarias batrachus reared under 23-25ㄷ. Nippon Suisan Gakkaishi. 58, 2033-2037. 